Vegetalika. 2017. 6(2): 40-54

\title{
Tanggapan Padi Lokal (Oryza sativa L.) Melati Menoreh terhadap Sistem Budidaya Semi Organik dan Organik dengan Jarak Tanam Berbeda di Kalibawang, Kulon Progo
}

\section{Response of Local Rice (Oryza sativa L.) Melati Menoreh on Semi Organic and Organic Systems with Different Plant Spacing in Kalibawang, Kulon Progo}

\author{
Reni Afiat ${ }^{1)}$, Didik Indradewa ${ }^{2 *}$, Dody Kastono ${ }^{2)}$ \\ 1) Program Studi Agronomi, Fakultas Pertanian, Universitas Gadjah Mada \\ 2) Departemen Budidaya Pertanian, Fakultas Pertanian, Universitas Gadjah Mada \\ *) Penulis untuk korespodensi E-mail: didikindradewa54@yahoo.com
}

\begin{abstract}
The need of rice is increasing every year in line with population growth. Increased demand for rice needs are not accompanied with rice production in the country, therefore rice imports are required. To fullfill of rice demand, good varieties and environment are needed for cultivation activities. This research aims to study the response of Melati Menoreh grown in semi-organic and organic with different plant spacing, as well as determining the proper plant spacing for each cultivation. The research was conducted in Banjararum, Kalibawang, Kulon Progo, Yogyakarta in February to August 2016. The research was arranged in multi-location (oversite) two-factor with five plots of farmers as replication. The first was factor the culture system consisting of two levels, namely semi-organic and organic. The second was plant factor spacing consisting of two levels, i.e. $20 \mathrm{~cm} \times 40 \mathrm{~cm}$ and $25 \mathrm{~cm} \times 40 \mathrm{~cm}$. Changes from semi-organic to organic farming systems caused a decrease in growth, total chlorophyll, and amylose content of rice which caused fluffier rice, but similar yield, i.e. 7,31 tons/ha on semi-organic and 7,71 tons/ha on organic farming systems. Changes in the system could increase the weight of the rice from 3,46 tons/ha to 4,05 tons/ha. Wider plant spacing could increase the total chlorophyll and amylose content of rice which caused parboiled rice, and increased of rice in which the spacing of $25 \mathrm{~cm} \times 40 \mathrm{~cm}$ yield of weight up to 4,32 tons/ha, and 3,19 tons/ha $20 \mathrm{~cm} \times 40 \mathrm{~cm}$ plant spacing.
\end{abstract}

Keywords: Melati Menoreh, organic, plant spacing, semi-organic

\section{INTISARI}

Kebutuhan beras setiap tahun semakin bertambah seiring dengan laju pertumbuhan penduduk. Meningkatnya permintaan kebutuhan beras tersebut tidak diimbangi dengan produksi beras di dalam negeri, sehingga untuk pemenuhannya dilakukan impor beras. Oleh karena itu, untuk dapat memenuhi kebutuhan beras, diperlukan varietas dan lingkungan yang mendukung untuk kegiatan budidaya. Penelitian ini bertujuan untuk mempelajari tanggapan padi Melati Menoreh yang ditanam secara semi organik dan organik dengan jarak tanam berbeda, serta menentukan jarak tanam yang tepat untuk 
masing-masing cara budidaya. Penelitian dilaksanakan di Desa Banjararum, Kalibawang, Kulonprogo, Yogyakarta pada bulan Februari-Agustus 2016. Penelitian disusun dalam rancangan multilokasi (oversite) dua faktor dengan lima petak petani sebgai ulangan. Faktor pertama sistem budidaya yang terdiri dari 2 aras, yaitu semi organik dan organik. Faktor kedua jarak tanam yang terdiri dari 2 aras, yaitu $20 \mathrm{~cm} \times 40 \mathrm{~cm}$ dan $25 \mathrm{~cm} \times 40$ $\mathrm{cm}$. Perubahan sistem budidaya dari semi organik menjadi organik menyebabkan penurunan kadar klorofil total, pertumbuhan, dan kadar amilosa beras yang menyebabkan beras pulen, serta hasil gabah kering panen yang tidak berbeda, yaitu 7,31 ton/ha pada semi organik dan 7,71 ton/ha pada organik. Tetapi pergantian sistem budidaya tersebut dapat meningkatkan bobot beras yaitu dari 3,46 ton/ha menjadi 4,05 ton/ha. Jarak tanam yang lebih lebar dapat meningkatkan kadar klorofil total dan kadar amilosa beras yang menyebabkan beras pera, serta meningkatkan bobot beras di mana pada jarak tanam 25 $\mathrm{cm} \times 40 \mathrm{~cm}$ menghasilkan 4,32 ton/ha, sedangkan jarak tanam $20 \mathrm{~cm} \times 40 \mathrm{~cm}$ menghasilkan 3,19 ton/ha.

Kata kunci: Jarak tanam, Melati Menoreh, organik, semi organik

\section{PENDAHULUAN}

Padi merupakan jenis tanaman yang menghasilkan bahan pangan berupa beras. Kebutuhan beras setiap tahun semakin bertambah seiring dengan laju pertumbuhan penduduk. Meningkatnya permintaan kebutuhan beras tersebut tidak diimbangi dengan produksi beras di dalam negeri, sehingga untuk pemenuhannya dilakukan impor beras. Oleh karena itu, untuk dapat memenuhi kebutuhan beras, diperlukan varietas dan lingkungan yang mendukung untuk kegiatan budidaya.

Padi Melati Menoreh merupakan padi lokal unggulan dari Kulonprogo, yang produksinya dapat mencapai 7-9 ton per hektar (Pemerintah Kulonprogo, 2013). Menurut Stoate et al. (2001), sistem pertanian non-organik mampu meningkatkan produksi tanaman. Namun juga memberikan dampak negatif bagi lingkungan, yaitu dapat menurunkan kandungan bahan organik dan kesuburan tanah. Soepandy et al. (2012) menyampaikan bahwa penurunan kandungan bahan organik secara terus menerus dapat menyebabkan penurunan produktivitas lahan. Namun, Nguluu et al. (1887) menjelaskan bahwa pemberian pupuk organik secara bersamaan dengan pupuk anorganik akan lebih baik dibandingkan dengan pemberian pupuk anorganik saja. Hal ini didukung oleh hasil penelitian Utami et al. (2010), bahwa bobot kering tajuk tertinggi pada sistem budidaya semi organik sebesar 33,3 g, sedangkan bobot terendah ditunjukkan oleh sistem budidaya organik sebesar $13,86 \mathrm{~g}$. 
Reni Afiat et al., / Vegetalika. 2017. 6(2): 40-54

Faisul-ur-Rasool et al. (2012) menyatakan bahwa jarak tanam merupakan salah satu upaya modifikasi lingkungan untuk mengoptimalkan hasil tanaman. Jarak tanam yang optimal akan mengefisienkan pemanfaatan radiasi matahari dan nutrisi dalam tanah (Sohel et al., 2009). Menurut Lin et al. (2009), jarak tanam yang lebar dapat memperbaiki kemampuan tanaman dalam penyekapan cahaya dan dapat meningkatkan hasil. Menurut Sohel et al. (2009), jarak tanam yang tepat akan menghasilkan pertumbuhan, jumlah anakan, dan hasil yang maksimum, serta meningkatkan tanaman dalam memanfaatkan cahaya matahari dan unsur hara dalam tanah. Jarak tanam yang terlalu rapat dapat mengakibatkan terjadinya kompetisi antar tanaman, sehingga pertumbuhan tanaman menjadi terhambat dan hasil menjadi rendah. Namun, jarak tanam yang terlalu lebar juga berpotensi menurunkan hasil, karena adanya lahan yang tidak termanfaatkan.

Pada umumnya, padi yang ditanam dengan jarak tanam sempit akan mengalami penurunan jumlah anakan dan malai, malai yang lebih pendek, serta jumlah gabah per malai lebih sedikit (Siregar, 1981). Baloch et al. (2002) menyebutkan bahwa semakin lebar jarak tanam hingga batas optimum akan meningkatkan pertumbuhan tanaman, jumlah malai per rumpun, jumlah gabah per malai, dan bobot 1000 butir. Pada jarak tanam 22,5 $\mathrm{cm} \times 22,5 \mathrm{~cm}$ menghasilkan gabah 2,95 kg/petak, sedangkan jarak tanam $20 \mathrm{~cm} \times 20 \mathrm{~cm}$ dan $25 \mathrm{~cm}$ x $25 \mathrm{~cm}$ menghasilkan 2,30 dan 2,19 kg/petak, dengan luasan petak $9 \mathrm{~m}^{2}$.

Perbedaan kondisi lingkungan antara lahan dengan sistem budidaya semi organik dan organik salah satunya ada pada kandungan haranya. Perbedanaan kandungan hara tersebut akan menyebabkan perbedaaan pertumbuhan, aktivitas fisiologi yang terjadi di dalam tanaman, dan produktivitas yang berbeda. Oleh karena itu, perlu diketahui tanggapan padi Melati Menoreh yang ditanam secara semi organik dan organik dengan jarak tanam yang berbeda, serta jarak tanam yang tepat untuk masing-masing cara budidaya agar diperoleh hasil yang terbaik.

\section{BAHAN DAN METODE}

Penelitian dilaksanakan di Desa Banjararum, Kecamatan Kalibawang, Kabupaten Kulonprogo, Daerah Istimewa Yogyakarta pada bulan Februari-Agustus 2016. Alat yang digunakan meliputi penggaris/meteran, timbangan, luxmeter, thermo-hygrometer, leafareameter, oven, alat-alat pertanian dan alat bantu lainnya, serta alat tulis dan kamera. Bahan yang digunakan adalah padi lokal Melati Menoreh. 
Perlakuan disusun dalam rancangan multilokasi (oversite) dua faktor dengan lima petak petani sebagai ulangan. Faktor pertama sistem budidaya yang terdiri dari 2 aras, yaitu secara semi organik dan organik. Faktor kedua jarak tanam yang terdiri dari 2 aras, yaitu $20 \mathrm{~cm}$ x $40 \mathrm{~cm}$ dan $25 \mathrm{~cm}$ x $40 \mathrm{~cm}$.

Variabel pengamatan yang diamati terdiri atas: (1) variabel pengamatan lingkungan, meliputi suhu udara, kelembaban udara, dan intensitas cahaya; (2) variabel pengamatan periodik, meliputi tinggi tanaman dan jumlah anakan; (3) variabel pengamatan destruktif, meliputi panjang akar, luas permukaan akar, luas daun, bobot kering akar dan tajuk; (4) variabel fisiologis berupa kadar klorofil total; (5) variabel pengamatan komponen hasil, meliputi jumlah anakan produktif, panjang malai, bulir gabah per malai, persentase gabah isi, bobot 1000 bulir, dan produktivitas; (6) variabel kualitas berupa kadar amilosa beras. Data yang terkumpul dianalisis menggunakan analisis varians pada level 5 \% dan dilanjutkan dengan Duncan's Multiple Range Test (DMRT) jika hasil analisis varian menunjukkan perbedaan yang nyata antar perlakuan.

\section{HASIL DAN PEMBAHASAN}

Lingkungan merupakan tempat tumbuh tanaman yang memiliki peranan dan pengaruh terhadap pertumbuhan dan perkembangan tanaman. Pentingnya dilakukan pengamatan terhadap lingkungan adalah untuk membandingkan kondisi lingkungan yang digunakan dengan kesesuaian kriteria yang dibutuhkan tanaman dalam kondisi optimum.

Tabel 1. Intensitas cahaya, cuhu, dan kelembaban lingkungan penelitian

\begin{tabular}{lccccc}
\hline & $4 \mathrm{mspt}$ & $6 \mathrm{mspt}$ & $8 \mathrm{mspt}$ & $10 \mathrm{mspt}$ & $12 \mathrm{mspt}$ \\
\hline Intensitas Cahaya (lux) & 23,43 & 22,17 & 17,45 & 22.97 & 12,35 \\
Suhu ( $\left.{ }^{\circ} \mathrm{C}\right)$ & 37,40 & 34,00 & 36,40 & 39,40 & 32,20 \\
Kelembaban (\%) & 70,50 & 73,80 & 60,70 & 57,50 & 69,40 \\
\hline
\end{tabular}

Pengukuran suhu pada lokasi menunjukkan keadaan yang tidak sesuai dengan syarat tumbuh tanaman padi. Menurut Balai Pengkajian Teknologi Pertanian (2009), suhu yang sesuai untuk tanaman padi antara $18-35^{\circ} \mathrm{C}$. Sedangkan suhu di lokasi mencapai 32$39{ }^{\circ} \mathrm{C}$. Suhu tinggi terjadi akibat cuaca yang ekstrim. Menurut Matsui et al. (1976) cit. Balai Besar Penelitian Tanaman Padi (2015), suhu tinggi sangat mempengaruhi pembungaan tanaman padi. Suhu tinggi yang terjadi saat pembungaan dapat menurunkan viabilitas tepungsari sehingga menyebabkan kehilangan hasil. Pada suhu di atas $35^{\circ} \mathrm{C}$ dapat menaikkan sterilitas gabah. Namun, kelembaban udara di lokasi pengamatan 
Reni Afiat et al., / Vegetalika. 2017. 6(2): 40-54

menunjukkan keadaan yang sangat sesuai dengan syarat tumbuh tanaman padi. Menurut Balai Pengkajian Teknologi Pertanian (2009), tanaman padi membutuhkan lingkungan dengan kelembaban udara antara 33-90\%. Kelembaban pada lokasi penelitian berkisar antara $57-73 \%$.

Tabel 2. Kadar klorofil total $(\mathrm{mg} / \mathrm{g})$

\begin{tabular}{lccc}
\hline \multirow{2}{*}{ Jarak Tanam } & \multicolumn{2}{c}{ Sistem Budidaya } & \multirow{2}{*}{ Rerata } \\
\cline { 2 - 3 } & Semi Organik & Organik & 0,692 \\
$20 \mathrm{~cm} \times 40 \mathrm{~cm}$ & $0,619 \mathrm{c}$ & $0,764 \mathrm{~b}$ & 0,816 \\
\hline Rerata & $0,910 \mathrm{a}$ & $0,723 \mathrm{bc}$ & $(+)$ \\
\hline Koefisien Keragaman (\%) & 0,764 & 0,744 & 9,68 \\
\hline
\end{tabular}

Keterangan: (+) ada interaksi, angka dalam kolom dan baris diikuti oleh huruf sama menunjukkan tidak berbeda nyata berdasarkan DMRT pada taraf kesalahan $5 \%$

Warna hijau pada daun erat kaitannya dengan kadar klorofil pada daun. Menurut Taiz and Zeiger (2002), warna hijau pada daun terbentuk karena klorofil menyerap cahaya merah dan biru, sedangkan cahaya hijau dipantulkan. Pergantian cara budidaya dari semi organik menjadi organik pada jarak tanam rapat $20 \mathrm{~cm}$ x $40 \mathrm{~cm}$ menyebabkan kenaikan kadar klorofil total pada daun. Sebaliknya, pada jarak tanam renggang $25 \mathrm{~cm} \times 40 \mathrm{~cm}$ menyebabkan penurunan kadar klorofil total pada daun. Kadar klorofil daun padi akan meningkat jika menggunakan jarak tanam lebih lebar pada sistem semi organik dan pada sistem organik menggunakan jarak tanam lebih sempit. Secara kesuluruhan, kadar klorofil daun tertinggi diperoleh pada tanaman padi yang ditanam secara semi organik dengan jarak tanam renggang $25 \mathrm{~cm} \times 40 \mathrm{~cm}$.

Sistem semi organik menggunakan tambahan pupuk anorganik. Pupuk anorganik dapat diserap dengan mudah oleh tanaman, sedangkan pupuk organik bersifat lepas lambat. Hal tersebut diduga dapat menyebabkan kadar klorofil pada daun meningkat, akibat penyerapan unsur $\mathrm{N}$ yang meningkat. Jarak tanam akan mempengaruhi tanaman dalam penyerapan unsur hara. Semakin rapat jarak tanam, meningkatkan kompetisi dalam penyerapan unsur hara dan begitu pula sebaliknya.

Daun merupakan organ di mana proses fotosintesis terjadi. Hasil fotosintesis yang disebut fotosintat akan ditranslokasikan ke seluruh organ tanaman untuk pertumbuhan dan perkembangannya. Luas daun sangat berpengaruh terhadap fotosintat yang dihasilkan oleh tanaman. Semakin luas daun dapat diasumsikan bahwa semakin tinggi penyerapan cahaya oleh daun. Tingginya penyerapan cahaya akan meningkatkan proses 
fotosintesis dan menghasilkan fotosintat yang tinggi, jika tidak ada faktor pembatas yang lain.

Tabel 3. Luas daun $\left(\mathrm{cm}^{2}\right)$

\begin{tabular}{lccc}
\hline \multicolumn{1}{c}{ Sistem } & \multirow{2}{*}{ Jarak Tanam } & \multicolumn{2}{c}{ Luas Daun $\left(\mathrm{cm}^{2}\right)$} \\
\cline { 3 - 4 } Semi Organik & $20 \mathrm{~cm} \times 40 \mathrm{~cm}$ & $1851,10 \mathrm{~b}$ & $12 \mathrm{mspt}$ \\
& $25 \mathrm{~cm} \times 40 \mathrm{~cm}$ & $3725,10 \mathrm{a}$ & $197,94 \mathrm{c}$ \\
& $20 \mathrm{~cm} \times 40 \mathrm{~cm}$ & $869,10 \mathrm{c}$ & $483 \mathrm{~b}$ \\
\hline Organik & $25 \mathrm{~cm} \times 40 \mathrm{~cm}$ & $886,00 \mathrm{c}$ & $286,29 \mathrm{~b}$ \\
& & $(+)$ & $(+)$ \\
\hline Interaksi & & 2,54 & 5,54 \\
\hline CV $(\%)$ & & &
\end{tabular}

Keterangan: (+) ada interaksi, angka dalam kolom dan baris diikuti oleh huruf sama menunjukkan tidak berbeda nyata berdasarkan DMRT pada taraf kesalahan $5 \%$

Pada sistem budidaya semi organik, penerapan jarak tanam renggang menyebabkan peningkatan luas daun. Sedangkan pada sistem budidaya organik, jarak tanam menyebabkan luas daun tidak berbeda pada umur $8 \mathrm{mspt}$, namun pada umur 12 mspt jarak tanam renggang menyebabkan penurunan luas daun.

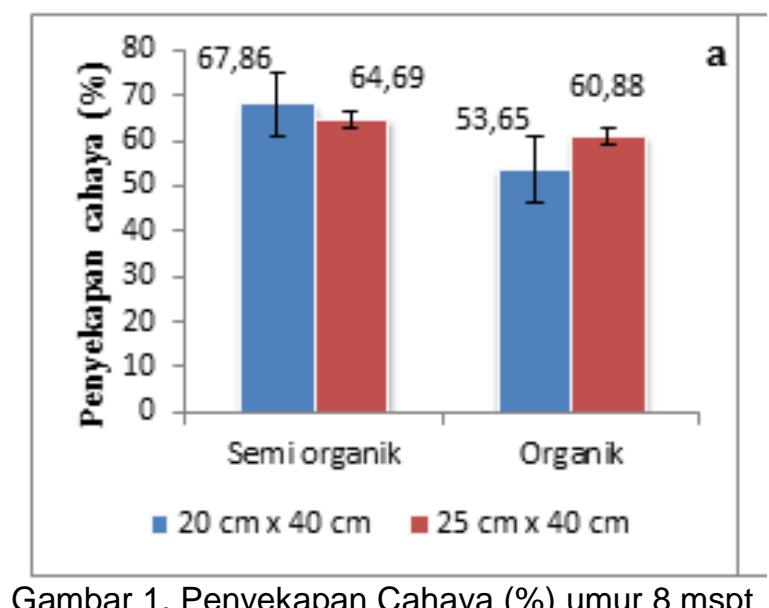

Penyekapan cahaya berpengaruh terhadap kemampuan tanaman dalam menyerap cahaya, dan banyak sedikitnya cahaya yang dapat diserap oleh tanaman yang nantinya akan berpengaruh terhadap proses fotosintesis. Menurut Gardner et al. (2008), perkembangan luas daun menyebabkan peningkatan penyerapan cahaya oleh daun. Pada Gambar 1. dijelaskan bahwa padi yang ditanam secara semi organik dengan jarak tanam rapat mampu menyekap cahaya lebih banyak daripada yang lain, sedangkan padi yang ditanam secara organik dengan jarak tanam rapat menyekap cahaya paling sedikit. 
Reni Afiat et al., / Vegetalika. 2017. 6(2): 40-54
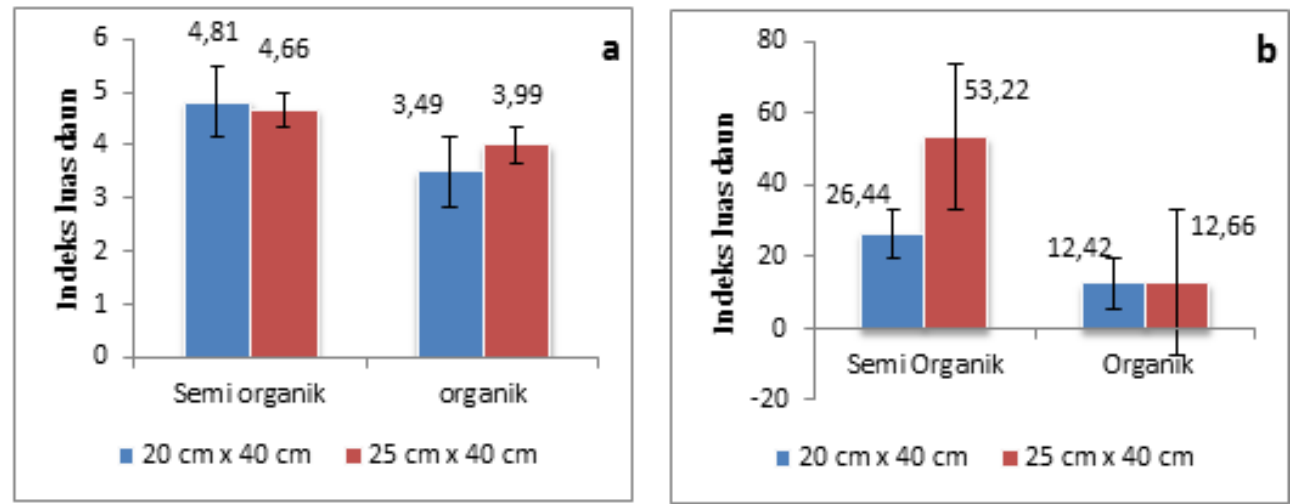

Gambar 2. Indeks Luas Daun (a) umur 4 mspt (b) umur 8 mspt

Indeks luas daun merupakan luas daun total pada tiap satuan luas lahan. Menurut Yoshida (1981), indeks luas daun akan mencapai maksimal pada fase sebelum berbunga. Padi memiliki indeks luas daun optimal antara 4-7. Pada saat tanaman berumur $4 \mathrm{mspt}$, indeks luas daun tertinggi dicapai oleh padi yang ditanam secara semi organik dengan jarak tanam rapat. Padi semi organik dengan jarak tanam renggang $25 \mathrm{~cm} \times 40 \mathrm{~cm}$ memiliki indeks luas daun tertinggi saat berumur 8 mspt. Menurut Ishizuka (1969), indeks luas daun dapat dipengaruhi oleh jarak tanam atau populasi. Dalam keadaan populasi yang tetap, indeks luas daun sangat ditentukan oleh jumlah anakan. Sehingga indeks luas daun optimal tergantung pada cara pengaturan jarak tanam dan populasi anakan.

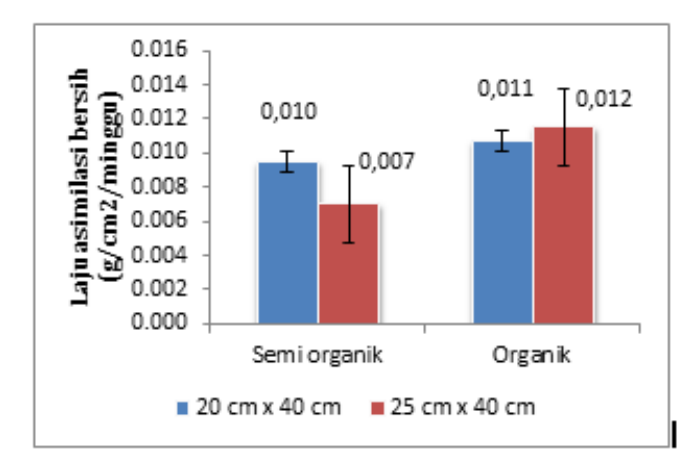

Gambar 3. Laju Asimilasi Bersih (g/cm²/minggu) Umur 4-8 mspt

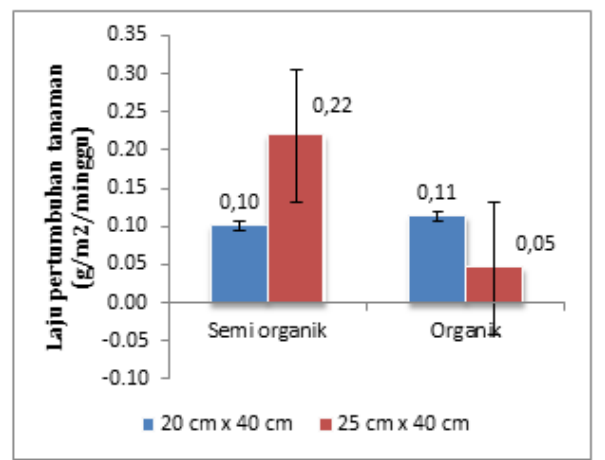

Gambar 4. Laju Pertumbuhan Tanaman (g/m²/minggu) Umur 4-8 mspt

Menurut Gardner et al. (2008), laju asimilasi bersih merupakan kecepatan tanaman dalam menghasilkan fotosintat yang dapat diketahui melalui bobot kering. Sedangkan laju pertumbuhan tanaman menggambarkan kecepatan tanaman dalam mentranslokasikan asimilat yang dihasilkan. Pada Gambar 3. dijelaskan bahwa padi yang ditanam secara 
organik dengan jarak tanam renggang $25 \mathrm{~cm} \times 40 \mathrm{~cm}$ memiliki laju asimilasi bersih tertinggi. Pada Gambar 4. dijelaskan bahwa padi yang ditanam pada sistem semi organik dengan jarak tanam renggang $25 \mathrm{~cm} \times 40 \mathrm{~cm}$ memiliki laju pertumbuhan tertinggi, yaitu $0,22 \mathrm{~g} / \mathrm{m}^{2} / \mathrm{ming} g \mathrm{u}$.

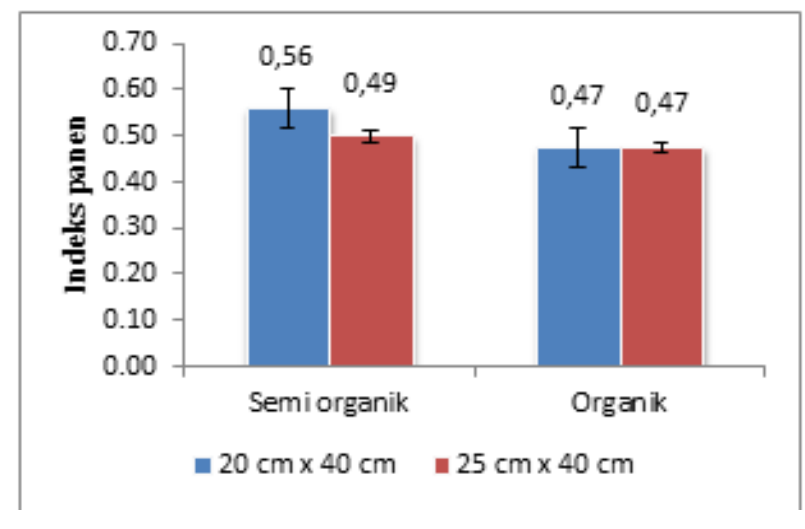

Gambar 5. Indeks Panen

Indeks panen adalah perbandingan antara bobot kering hasil ekonomis terhadap bobot kering hasil biologis. Angka ini menunjukkan efisiensi alokasi bahan kering dalam tanaman. Menurut Zapata et al. (1983), hasil dari suatu tanaman dapat ditingkatkan dengan jalan meningkatkan indeks panen atau produksi bahan kering total. Namun, peningkatan hasil bahan kering tidak selalu disertai oleh kenaikan hasil gabah kering. Sehingga tingginya produksi biomassa belum menggambarkan tingginya hasil gabambah. Berdasarkan Gambar 5. dijelaskan bahwa indeks panen tertinggi dicapai oleh padi yang ditanam secara semiorganik dengan jarak tanam rapat $20 \mathrm{~cm}$ x $40 \mathrm{~cm}$.

Pergantian sistem budidaya dari semi organik menjadi organik dan jarak tanam menyebabkan bobot kering total padi umur $4 \mathrm{mspt}$ tidak berbeda. Sedangkan pada saat padi berumur 8 mspt terjadi perbedaan bobot kering total tanaman. Pergantian cara budidaya dengan jarak tanam rapat menyebabkan penurunan bobot kering total tanaman. Begitu pula pada jarak tanam renggang. Namun, terjadi peningkatan bobot kering total pada tanaman yang ditanam dengan jarak tanam renggang $25 \mathrm{~cm} \times 40 \mathrm{~cm}$, baik yang ditanam secara semi organik maupun organik. Dengan perkataan lain padi yang ditanam secara semi organik dengan jarak tanam renggang $25 \mathrm{~cm} \times 40 \mathrm{~cm}$ memiliki bobot paling tinggi. 
Reni Afiat et al., / Vegetalika. 2017. 6(2): 40-54

Tabel 4. Bobot kering total (g) umur $4 \mathrm{mspt}$

\begin{tabular}{lccc}
\hline \multirow{2}{*}{ Jarak Tanam } & \multicolumn{2}{c}{ Sistem Budidaya } & \multirow{2}{*}{ Rerata } \\
\cline { 2 - 4 } & Semi Organik & Organik & $3,84 \mathrm{p}$ \\
$20 \mathrm{~cm} \times 40 \mathrm{~cm}$ & 4,33 & 3,35 & $4,00 \mathrm{p}$ \\
$25 \mathrm{~cm} \times 40 \mathrm{~cm}$ & 4,04 & 3,96 & $(-)$ \\
\hline Rerata & $4,19 \mathrm{a}$ & $3,65 \mathrm{a}$ & 13,24 \\
\hline Koefisien Keragaman $(\%)$ & & & \\
\hline
\end{tabular}

Keterangan: (-) tidak ada interaksi, angka dalam kolom dan baris yang sama diikuti oleh huruf sama menunjukkan tidak berbeda nyata berdasarkan DMRT pada taraf kesalahan $5 \%$

Tabel 5. Bobot kering total (g) umur $8 \mathrm{mspt}$

\begin{tabular}{lccc}
\hline \multirow{2}{*}{ Jarak Tanam } & \multicolumn{2}{c}{ Sistem Budidaya } & \multirow{2}{*}{ Rerata } \\
\cline { 2 - 3 } & Semi Organik & Organik & 30,62 \\
$20 \mathrm{~cm} \times 40 \mathrm{~cm}$ & $37,63 \mathrm{ab}$ & $23,61 \mathrm{c}$ & 35,29 \\
$25 \mathrm{~cm} \times 40 \mathrm{~cm}$ & $42,89 \mathrm{a}$ & $27,69 \mathrm{bc}$ & $(+)$ \\
\hline Rerata & 40,26 & 25,65 & 12,22 \\
\hline Koefisien Keragaman (\%) & & & \\
\hline
\end{tabular}

Keterangan: (+) ada interaksi, angka dalam kolom dan baris diikuti oleh huruf sama menunjukkan tidak berbeda nyata berdasarkan DMRT pada taraf kesalahan $5 \%$

Tabel 6. Panjang akar total $(\mathrm{cm})$ umur $4 \mathrm{mspt}$

\begin{tabular}{lccc}
\hline \multirow{2}{*}{ Jarak Tanam } & \multicolumn{2}{c}{ Sistem Budidaya } & \multirow{2}{*}{ Rerata } \\
\cline { 2 - 3 } & Semi Organik & Organik & $116,54 \mathrm{p}$ \\
$20 \mathrm{~cm} \times 40 \mathrm{~cm}$ & 103,79 & 129,30 & $133,66 \mathrm{p}$ \\
$25 \mathrm{~cm} \times 40 \mathrm{~cm}$ & 97,51 & 169,81 & $(-)$ \\
\hline Rerata & $100,65 \mathrm{~b}$ & $149,56 \mathrm{a}$ & 4,86 \\
\hline Koefisien Keragaman $(\%)$ & & & \\
\hline
\end{tabular}

Keterangan: (-) tidak ada interaksi, angka dalam kolom dan baris yang sama diikuti oleh huruf sama menunjukkan tidak berbeda nyata berdasarkan DMRT pada taraf kesalahan $5 \%$.

Tabel 7. Panjang akar total $(\mathrm{cm})$ Umur $8 \mathrm{mspt}$

\begin{tabular}{lclc}
\hline \multirow{2}{*}{ Jarak Tanam } & \multicolumn{2}{c}{ Sistem Budidaya } & \multirow{2}{*}{ Rerata } \\
\cline { 2 - 3 } & Semi Organik & Organik & 257,39 \\
$20 \mathrm{~cm} \times 40 \mathrm{~cm}$ & $275,37 \mathrm{a}$ & $239,41 \mathrm{ab}$ & 228,84 \\
\hline Rerata & $193,05 \mathrm{~b}$ & $264,64 \mathrm{a}$ & $(+)$ \\
\hline Koefisien Keragaman $(\%)$ & 234,21 & 252,03 & 18,32 \\
\hline
\end{tabular}

Keterangan: (+) ada interaksi, angka dalam kolom dan baris diikuti oleh huruf sama menunjukkan tidak berbeda nyata berdasarkan DMRT pada taraf kesalahan $5 \%$.

Akar merupakan organ vegetatif tanaman yang berfungsi untuk memasok air, hara, dan mineral yang penting untuk pertumbuhan dan perkembangan tanaman (Gardner et al., 2008). Berdasarkan Tabel 6 pergantian cara budidaya dari semi organik menjadi organik menyebabkan kenaikan panjang akar total. Penggunaan jarak tanam rapat $20 \mathrm{~cm}$ x $40 \mathrm{~cm}$ dan jarak tanam renggang $25 \mathrm{~cm}$ x $40 \mathrm{~cm}$ menyebabkan panjang akar total tidak berbeda. Panjang akar total padi umur 4 mspt akan meningkat jika ditanam secara organik. Sedangkan pada Tabel 7. dijelaskan bahwa pergantian cara budidaya padi dari 
semi organik menjadi organik dengan jarak tanam rapat $20 \mathrm{~cm} \times 40 \mathrm{~cm}$ menyebabkan penurunan panjang akar total. Sedangkan pada jarak tanam renggang $25 \mathrm{~cm} \times 40 \mathrm{~cm}$ menyebabkan peningkatan penjang akar total. Tanaman padi memiliki junlah akar total terpanjang saat ditanam secara semi organik dengan jarak tanam rapat dan secara organik dengan jarak tanam renggang.

Tabel 8. Tinggi tanaman (cm), jumlah anakan, dan anakan produktif

\begin{tabular}{lccc}
\hline Sistem Budidaya & Tinggi Tanaman & Jumlah Anakan & Anakan Produktif \\
\hline Semi Organik & $98,03 \mathrm{a}$ & $11,04 \mathrm{a}$ & $10,00 \mathrm{a}$ \\
Organik & $90,36 \mathrm{~b}$ & $11,80 \mathrm{a}$ & $10,93 \mathrm{a}$ \\
\hline Jarak Tanam & & & \\
\hline $20 \mathrm{~cm}$ x $40 \mathrm{~cm}$ & $93,83 \mathrm{p}$ & $10,80 \mathrm{p}$ & $10,27 \mathrm{p}$ \\
$25 \mathrm{~cm}$ x $40 \mathrm{~cm}$ & $94,56 \mathrm{p}$ & $12,04 \mathrm{p}$ & $10,67 \mathrm{p}$ \\
\hline Interaksi & $(-)$ & $(-)$ & 11,97 \\
\hline CV $(\%)$ & 4,90 & 12,62 & $-)$ \\
\hline
\end{tabular}

Keterangan: (-) tidak ada interaksi, angka dalam kolom yang sama diikuti oleh huruf sama menunjukkan tidak berbeda nyata berdasarkan DMRT pada taraf kesalahan $5 \%$

Pergantian cara budidaya dari semi organik menjadi organik menyebabkan penurunan tinggi tanaman, namun tidak menyebabkan perbedaan jumlah anakan total dan produktif. Tanaman yang ditanam secara semi organik tumbuh lebih tinggi, yaitu mencapai $98,033 \mathrm{~cm}$. Jarak tanam rapat $20 \mathrm{~cm} \times 40 \mathrm{~cm}$ dan jarak tanam renggang $25 \mathrm{~cm} \times 40 \mathrm{~cm}$ menyebabkan tinggi tanaman dan jumlah anakan tidak berbeda.

Tabel 8. dijelaskan bahwa pergantian cara budidaya dari semi organik menjadi organik menyebabkan penurunan jumlah malai dan jumlah bulir gabah per malai. Penggunaan jarak tanam rapat $20 \mathrm{~cm} \times 40 \mathrm{~cm}$ dan renggang $25 \mathrm{~cm} \times 40 \mathrm{~cm}$ tidak memberikan perbedaan terhadap jumlah malai dan jumlah bulir gabah per malai padi kultivar Melati Menoreh. Gabah merupakan hasil ekonomis dari tanaman padi. Jumlah gabah permalai dapat menggambarkan produktivitas tanaman. Semakin banyak jumlah gabah per malai, diasumsikan akan semakin tinggi produktivitasnya. 
Reni Afiat et al., / Vegetalika. 2017. 6(2): 40-54

Tabel 9. Panjang malai $(\mathrm{cm})$ dan jumlah gabah per malai

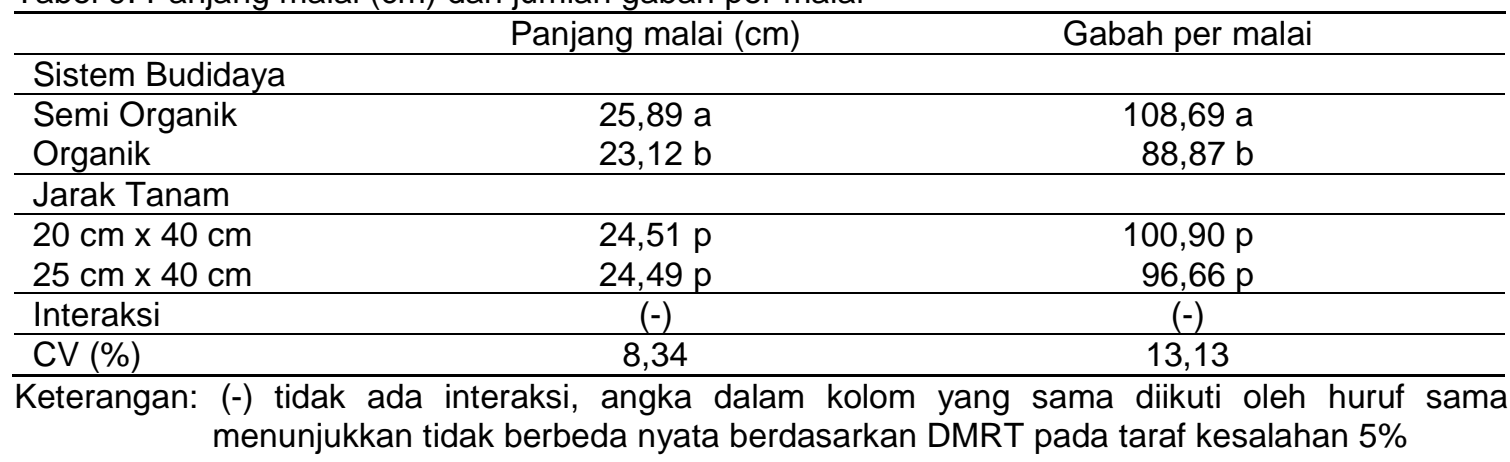

Tabel 10. Persentase gabah isi (\%)

\begin{tabular}{lccc}
\hline \multirow{2}{*}{ Jarak Tanam } & \multicolumn{2}{c}{ Sistem Budidaya } & \multirow{2}{*}{ Rerata } \\
\cline { 2 - 3 } & Semi Organik & Organik & \\
\hline $20 \mathrm{~cm} \times 40 \mathrm{~cm}$ & $66,60 \mathrm{c}$ & $76,44 \mathrm{~b}$ & 71,52 \\
$25 \mathrm{~cm} \times 40 \mathrm{~cm}$ & $60,31 \mathrm{c}$ & $87,66 \mathrm{a}$ & 73,99 \\
\hline Rerata & 63,46 & 82,05 & $(+)$ \\
\hline Koefisien Keragaman (\%) & \multicolumn{3}{c}{} \\
\hline Ken
\end{tabular}

Keterangan: (+) ada interaksi, angka dalam kolom dan baris diikuti oleh huruf sama menunjukkan tidak berbeda nyata berdasarkan DMRT pada taraf kesalahan 5\%

Pergantian cara budidaya dari semi organik ke organik menyebabkan peningkatan persentase gabah isi, baik pada jarak tanam rapat maupun renggang. Persentase gabah isi tertinggi dicapai pada budidaya secara organik menggunakan jarak tanam renggang 25 $\mathrm{cm} \times 40 \mathrm{~cm}$, dengan persentase $87,7 \%$. Persentase gabah isi dapat menggambarkan produktivitas tanaman. Apabila persentase gabah isi tinggi dapat diasumsikan bahwa produktivitas dari tanaman tersebut juga tinggi. Sebaliknya, jika banyak gabah yang hampa akan menyebabkan produktivitas menurun. Gabah hampa dapat disebabkan oleh serangan hama dan penyakit, penyerapan pupuk yang kurang maksimal, kekurangan jenis hara tertentu, dan cuaca yang tidak mendukung saat pengisian biji.

Tabel 11. Bobot 1000 bulir gabah dan gabah kering panen (ton/ha)

\begin{tabular}{lcc}
\hline & Bobot 1000 butir & Gabah Kering Panen (ton/ha) \\
\hline Sistem Budidaya & & \\
\hline Semi Organik & $22,16 \mathrm{a}$ & $7,31 \mathrm{a}$ \\
Organik & $22,22 \mathrm{a}$ & $7,71 \mathrm{a}$ \\
\hline Jarak Tanam & $23,01 \mathrm{p}$ & $7,25 \mathrm{p}$ \\
\hline $20 \mathrm{~cm} \times 40 \mathrm{~cm}$ & $21,36 \mathrm{p}$ & $7,77 \mathrm{p}$ \\
$25 \mathrm{~cm}$ x $40 \mathrm{~cm}$ & $(-)$ & $(-)$ \\
\hline Interaksi & 7,73 & 11,30 \\
\hline CV $(\%)$ & tidak ada interaksi, angka dalam kolom yang sama diikuti oleh huruf sama \\
\hline Keterangan: & $(-)$ &
\end{tabular}


Pergantian cara budidaya dari semi organik menjadi organik menyebabkan bobot 1000 butir gabah dan gabah kering panen (ton/ha) tidak berbeda. Hal ini disebabkan oleh jumlah malai pada padi semi organik dan organik sama. Selain itu, pada parameter bobot 1000 butir gabah juga menunjukkan hasil yang sama. Meskipun pergantian cara budidaya tersebut menyebabkan pemendekan panjang malai dan jumlah bulir per malai padi organik lebih sedikit. Namun, persentase bulir isi padi organik lebih tinggi, sehingga tidak terjadi perbedaan pada bobot 1000 bulir dan bobot gabah kering panen.

Penerapan jarak tanam rapat $20 \mathrm{~cm} \times 40 \mathrm{~cm}$ dan renggang $25 \mathrm{~cm} \times 40 \mathrm{~cm}$ menyebabkan bobot gabah kering panen tidak berbeda. Hal ini disebabkan oleh jumlah malai dan bobot 1000 bulir gabah yang sama. Namun pada persentase bulir isi padi yang ditanam dengan jarak tanam renggang memiliki presentase lebih tinggi. Tidak terjadi perubahan bobot karena jumlah gabah permalai cenderung lebih sedikit, tetapi presentase bulir isinya lebih tinggi.

Tabel 12. Bobot beras (ton/ha) padi melati menoreh pada sistem budidaya dan jarak tanam berbeda

\begin{tabular}{lccc}
\hline \multirow{2}{*}{ Jarak Tanam } & \multicolumn{2}{c}{ Sistem Budidaya } & \multirow{2}{*}{ Rerata } \\
\cline { 2 - 3 } & Semi Organik & Organik & $3,19 \mathrm{q}$ \\
$20 \mathrm{~cm} \times 40 \mathrm{~cm}$ & 3,17 & 3,20 & $4,32 \mathrm{p}$ \\
$25 \mathrm{~cm} \times 40 \mathrm{~cm}$ & 3,74 & 4,90 & $(-)$ \\
\hline Rerata & $3,46 \mathrm{~b}$ & $4,05 \mathrm{a}$ & 10,91
\end{tabular}

Keterangan: (-) tidak ada interaksi, angka dalam kolom dan baris yang sama diikuti oleh huruf sama menunjukkan tidak berbeda nyata berdasarkan DMRT pada taraf kesalahan $5 \%$

Tidak terdapat interaksi antara cara budidaya dan jarak tanam terhadap produktivitas beras dari padi kultivar Melati Menoreh (Tabel 12.). Sistem budidaya semi organik dan organik memberikan pengaruh terhadap produktivitas beras, di mana produktivitas beras hasil padi organik lebih tinggi dibandingkan semi organik. Jarak tanam renggang $25 \mathrm{~cm} \times 40 \mathrm{~cm}$ dapat meningkatkan produktivitas beras jika dibandingkan dengan jarak tanam rapat $20 \mathrm{~cm} \times 40 \mathrm{~cm}$. 
Reni Afiat et al., / Vegetalika. 2017. 6(2): 40-54
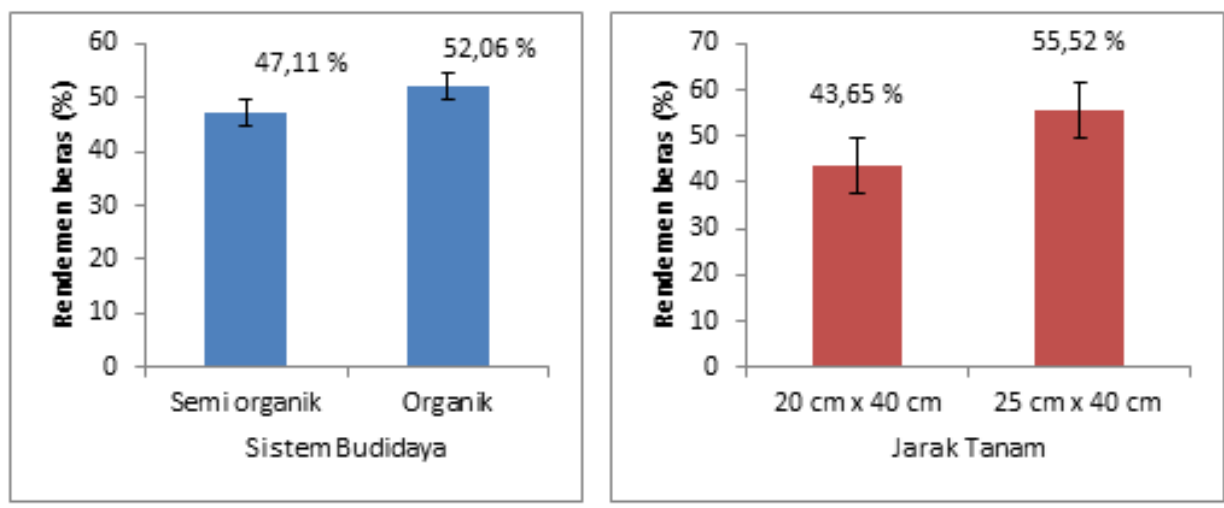

Gambar 6. Rendemen Beras terhadap Gabah Kering Panen

Hasil bobot gabah kering panen tidak menunjukkan perbedaan, namun terjadi perbedaan pada bobot beras. Hal ini dapat disebabkan oleh rendemen beras terhadap gabah kering panen. Rendemen di sini dapat diartikan sebagai perbandingan bobot beras yang dihasilkan dari gabah kering panen. Berikut adalah rendemen beras dari padi Melati Menoreh terhadap gabah kering panen. Dalam Gambar 6. dapat dijelaskan bahwa padi yang ditanam secara organik menghasilkan rendemen yang lebih tinggi, yaitu 52,06 \%. Angka tersebut dapat diartikan dari $100 \mathrm{~kg}$ gabah kering panen akan menghasilkan beras $52,06 \mathrm{~kg}$. Jarak tanam renggang $25 \mathrm{~cm} \times 40 \mathrm{~cm}$ juga menghasilkan rendemen beras terhadap gabah kering panen yang tinggi yaitu mencapai $55,52 \%$.

Tabel 13. Kadar Amilosa Beras (\%)

\begin{tabular}{lccc}
\hline \multirow{2}{*}{ Jarak Tanam } & \multicolumn{2}{c}{ Sistem Budidaya } & \multirow{2}{*}{ Rerata } \\
\cline { 2 - 3 } & Semi Organik & Organik & 23,664 \\
$20 \mathrm{~cm} \times 40 \mathrm{~cm}$ & $24,554 \mathrm{c}$ & $22,775 \mathrm{a}$ & 24,764 \\
$25 \mathrm{~cm} \times 40 \mathrm{~cm}$ & $23,553 \mathrm{~b}$ & $25,975 \mathrm{~d}$ & $(+)$ \\
\hline Rerata & 24,053 & 24,375 & 0,50 \\
\hline Koefisien Keragaman $(\%)$ & & & 0 \\
\hline
\end{tabular}

Keterangan: (+) ada interaksi, angka dalam kolom dan baris diikuti oleh huruf sama menunjukkan tidak berbeda nyata berdasarkan DMRT pada taraf kesalahan $5 \%$

Pada jarak tanam lebih rapat $20 \mathrm{~cm} \times 40 \mathrm{~cm}$ penggantian sistem budidaya menurunkan kadar amilosa. Sebaliknya pada jarak tanam lebih renggang $25 \mathrm{~cm} \times 40 \mathrm{~cm}$, penggantian sistem budidaya dari semi organik menjadi organik meningkatkan kadar amilosa beras. Kadar amilosa terendah dijumpai pada beras organik yang ditanam dengan jarak tanam lebih sempit. Kadar amilosa yang rendah diduga karena asimilat yang dihasilkan tanaman dapat dimanfaatkan oleh bagian tanaman yang lain secara optimal. Amilosa merupakan salah satu penyusun pati. Pati merupakan bahan utama yang 
dihasilkan oleh tanaman untuk menyimpan kelebihan glukosa yang merupakan produk dari fotosintesis.

Menurut Badan Standardisasi Nasional (2008), kadar amilosa pada beras mempengaruhi sifat pemekaran volume nasi dan kepulenan. Semakin tinggi kadar amilosanya, semakin mekar nasinya. Sebaliknya, semakin rendah kadar amilosa pada beras, semakin pulen nasi yang dihasilkan. Nasi yang mekar akan keras ketika dingin (pera), sedangkan nasi yang teksturnya pulen, ketika dingin tidak kering dan rasanya enak. Berdasarkan kadar amilosanya, beras dapat digolongkan menjadi 4, yaitu beras beramilosa tinggi/pera (>25\%), beras beramilosa sedang/pulen (20-25\%), beras beramilosa rendah/sangat pulen (15-20\%), dan beras dengan kadar amilosa sangat rendah/ketan $(<15 \%)$.

\section{KESIMPULAN}

1. Perubahan cara budidaya dari semi organik menjadi organik menyebabkan penurunan penurunan kadar klorofil total, pertumbuhan, dan kadar amilosa beras yang menyebabkan beras pulen, serta hasil gabah kering panen yang tidak berbeda, yaitu 7,31 ton/ha pada semi organik dan 7,71 ton/ha pada organik. Jarak tanam yang lebih lebar dapat meningkatkan kadar klorofil total dan kadar amilosa beras yang menyebabkan beras pera, serta meningkatkan bobot beras di mana pada jarak tanam $25 \mathrm{~cm} \times 40 \mathrm{~cm}$ menghasilkan 4,32 ton/ha, sedangkan jarak tanam $20 \mathrm{~cm} \times 40 \mathrm{~cm}$ menghasilkan 3,19 ton/ha.

2. Jarak tanam yang tepat untuk padi Melati Menoreh adalah $25 \mathrm{~cm} \times 40 \mathrm{~cm}$ pada sistem semi organik dan $20 \mathrm{~cm} \times 40 \mathrm{~cm}$ pada sistem organik.

\section{DAFTAR PUSTAKA}

Badan Standardisasi Nasional. 2008. Beras SNI 6128:2008. Badan Standardisasi Nasional, Jakarta.

Balai Besar Penelitian Tanaman Padi. 2015. Pengaruh perubahan iklim terhadap hasil padi. Balai besar penelitian tanaman padi. Subang, Jawa Barat. <http://bbpadi.litbang.pertanian.go.id/>. Diakses tanggal 25 Maret 2017. 
Reni Afiat et al., / Vegetalika. 2017. 6(2): 40-54

Balai Pengkajian Teknologi Pertanian. 2009. Budidaya tanaman padi. Badan Ketahanan Pangan dan Penyuluh Pertanian Aceh bekerja sama dengan Balai Pengkajian Teknologi Pertanian NAD. Aceh.

Baloch, A.W., A.M. Soomoro, M.A. Javed, M. Ahmed, H.R. Bughio, M.S Bughio and N.N. Mastoi. 2002. Optimum plant density for high yield in rice (Oryza sativa L.). Asian Journal of Plant Sciences. 1: 25-27.

Faisul-ur-Rasool, R. Habib and M.I. Bhat. 2012. Evaluation of plant spacing and seedlings per hill on rice (Oryza sativa L.) productivity under temperate conditions. Pakistan Journal of Agricultural Sciences. 49: 169-172.

Gardner, F.P., R.B. Pearce, and R.L. Mitchell. 2008. Physiology of crop plants (fisiologi tanaman budidaya, alih bahasa: H. Susilo). Universitas Indonesia (UI-Press), Jakarta.

Ishizuka, Y. 1969. Engineering for Higher Yields. In: Eastin J.D., et al. (Ed.) Physiological aspect of crop yield. ASA-CSSA. Madison, Wisconsin, USA.

Lin, X.Q., D.F. Zhu, H.Z. Chen, S.H. Cheng, and N. Uphoff. 2009. Effect of plant density and nitrogen fertilizer rates on grain yield and nitrogen uptake of hybrid rice (Oryza sativa L.). Journal of Agricultural Sciences. 50: 160-169.

Nguluu, S.N., M.E. Probert, R.J.K. Myers, dan S.A. Warring. 1887. Effect of tissue phosphorus concentration on mineralization of $\mathrm{N}$ from stylo and cowpea residues. Plant and Soil. 191: 139-146.

Pemerintah Kulonprogo. 2013. Padi asli kulonprogo diluncurkan ketua MPR RI. <http://www.kulonprogokab.go.id/v21/cetak.php?id=2994\#>. Diakses tanggal 29 Februari 2016.

Siregar, H. 1981. Budidaya tanaman padi di indonesia. Sastra Hudaya, Jakarta.

Soepandy, D., R. Poerwanto, dan Sobir. 2012. Sistem pertanian yang berkelanjutan. Departemen Agronomi dan Hortikuktura Fakultas Pertanian IPB. IPB press, Bogor.

Sohel, M.A.T., M.A.B. Siddique, M. Asaduzzaman, M.N. Alam, M.M. Karim. 2009. Varietal performance of transplant aman rice under different hill densities. Bangladesh Journal of Agricultural Research. 34: 33-39.

Stoate, C., Boatman, Borrlho, Carvalho, de Snoo, and Eden. 2001. A ecological impacts of arable intensification in Europe. Journal Enviromen Manage. 63:337.

Taiz, L. and E. Zeiger. 2002. Plant physioligy. Third Edition. Sinauer Associates, Sunderland.

Utami, S.N.H., M. Haji, dan N.W. Yuwono. 2010. Serapan hara n, p, k pada tanaman padi dengan berbagai lama penggunaan pupuk organik pada vertisol sragen. Jurnal IImu Tanah dan Lingkungan. 10: 1-13.

Yoshida, S. 1981. Fundamentals of rice crop science. International Rice Research Institute. Los Banos, Philippines.

Zapata, F.J. 1983. Rice anther culture at IRRI. In: Cell and tissue culture techniques for cereal crop improvement. Science Press. Beijing, China. 